\title{
INTERNMENT OF ALIEN SCIENTIFIC WORKERS
}

$\mathrm{I}^{\mathrm{I}}$ $\mathrm{N}$ his broadcast address to the nation on May 19 , the Prime Minister emphasized that "there will be many men and women in this island who when the ordeal comes on them, as come it will, will feel a comfort, and even a pride, that they are sharing the perils of our lads at the front. . . ." It would be foolish for anyone to ignore the imminence of such peril, and criminal not to anticipate it with the utmost rigour. In the present circumstances, men of science in Great Britain, whether British, naturalized or alien, cannot expect to be shown any form of preferential treatment.

We have made a few random inquiries and find that certain aliens (research workers, academic staff and students) in those universities which are already included in the areas announced for special treatment have been interned. It seems impossible that any man of science, no matter what his political or other views may be, could, in the extremely grave circumstances and in view of the amazing revelations concerning the activities of 'fifth columnists' in other countries, take exception to the internment of alien scientific workers and students. Many have established themselves as first-rate scientists, and a glance through the correspondence columns of NATURE will reveal that they have contributed much to the advancement of science while resident in Great Britain. Yet there can be no reason for assuming that there are no dangerous elements among such men of science, any more than among other types of alien refugees. One communication in reply to our inquiry, however, states : "I feel that there is little case for interning bona fide pure research scientists. The numbers of such intellectual workers would surely be too few to affect matters." To this one might fairly ask, what is the minimum number below which such people would prove ineffective, and are we always absolutely certain of an alien's bona fides, scientific or otherwise.

On the other hand, another well-known man of science, in response to our inquiry, pointed out that "the problem of lightening the hard lot of the innocent without assisting the fifth column is not a particularly easy one". Still more pointed is the remark from a third reply that: "The attitude of people at this University who have been interned is that the measure is obviously good from the country's point of view and they accept the matter philosophically." This contributor continues, "I think NATURE should hesitate before making any kind of general plea for release of scientific people who happen to be interned . . . there is always the possibility that some may be more interested than they seem to be in Nazi Germany, and the first thing at the moment is the safety of this country from all possible aspects." The contributor first quoted, however, after pointing out that there is little case for interning bona fide pure research scientists, continues: "I am sure it would be an excellent thing not only for general human standards, but also for our national war effort's efficiency, if Nature were to take the whole matter up."

There is no question, in our view, of "general human standards". We know, from inquiries, that those interned are well treated, and some may even be released again soon. We doubt if the internment of these men of science will affect very much our immediate "national war effort's efficiency", and we dare to say that any such loss to science is far outweighed by the all-important elimination of risk.

NATURE has striven hard for intellectual freedom in thought, word and action, but now we are seriously up against "evil things". Unity in a common cause must be kept paramount at present. We have attained it, and it is with pride that NATURE directs attention to the brilliant contributions to our war effort that many of our men of science are making in the Fighting Services and research organizations immediately connected with them, to say nothing of the many scientific workers carrying on at the home front. That unity must be preserved until victory is won. No risk is too great in our efforts to preserve it. The activities of the 'fifth column' have revealed to us what subversive potentialities exist in many countries for upsetting whatever unity of purpose has been achieved. Most men of science, therefore, while undoubtedly feeling sympathetic towards our alien scientific guests, must, on the other hand, consider that any form of preferential treatment for wcientific workers in this connexion would carry with it a grave element of risk which cannot be justified. 